$\begin{array}{ll}\text { Abstracta Iranica } & \begin{array}{l}\text { Abstracta Iranica } \\ \text { Revue bibliographique pour le domaine irano-aryen }\end{array} \\ & \text { Volume } 22 \mid \mathbf{2 0 0 1} \\ & \text { Comptes rendus des publications de } 1999\end{array}$

\title{
Zarbolamsāl wa kenāyāt. Peshawar, 1999, 306 p. [Proverbes et allusions]
}

\section{Nadjib Manalaï}

\section{(2) OpenEdition}

1 Journals

\section{Édition électronique}

URL : http://journals.openedition.org/abstractairanica/37182

DOI : 10.4000/abstractairanica.37182

ISSN : 1961-960X

Éditeur :

CNRS (UMR 7528 Mondes iraniens et indiens), Éditions de l'IFRI

\section{Édition imprimée}

Date de publication : 15 mai 2001

ISSN : 0240-8910

\section{Référence électronique}

Nadjib Manalaï, « ZZarbolamsāl wa kenāyāt. Peshawar, 1999, 306 p. [Proverbes et allusions] », Abstracta Iranica [En ligne], Volume 22 | 2001, document 575, mis en ligne le 15 février 2010, consulté le 13 octobre 2020. URL : http://journals.openedition.org/abstractairanica/37182 ; DOI : https://doi.org/ 10.4000/abstractairanica.37182

Ce document a été généré automatiquement le 13 octobre 2020.

Tous droits réservés 


\section{Zarbolamsāl wa kenāyāt. Peshawar, 1999, 306 p. [Proverbes et allusions]}

Nadjib Manalaï

1 Dictionnaire alphabétique de plus de 7000 proverbes, locutions idiomatiques et citations en Dari.

2 Les données fournies sont particulièrement précieuses. Quelques petits regrets cependant : certaines locutions populaires sont données avec leur prononciation orale

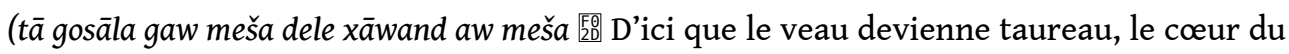
maître aura fondu) tandis que d'autres sont présentées avec une prononciation normalisée du dari écrit (zan e be mu ba mu hāye doxtare xāla aš menāzad 㡠 La femme sans cheveux est fière des cheveux de sa cousine). Les références des citations extraites de la littérature ne sont pas indiquées.

INDEX

Thèmes : 11.2. Littérature pashto et dari (Afghanistan)

\section{AUTEURS}

NADJIB MANALAÏ

INaLCO - Paris 